\title{
Correction to: The Political Thought of C.B. Macpherson
}

\section{Correction to}

(C) The Author(s) 2018

F. Cunningham, The Political Thought of C.B. Macpherson, Critical Political Theory and Radical Practice, https://doi.org/10.1007/978-3-319-94920-8

An error in the production process unfortunately led to publication of the book prematurely, before incorporation of the final corrections. The version supplied here has been corrected and approved by the author.

The updated original online version if this book can be found at https://doi.org/10.1007/978-3-319-94920-8 